\title{
University Students' Assessment of a Service-Learning Project for Developing Teaching Materials
}

\begin{abstract}
Juan Lucas Onieva López ${ }^{a}$, John Ramírez Leyton ${ }^{b}$, Raúl Cremades ${ }^{c}$, Soledad Ortega ${ }^{d},{ }^{a, c, d}$ Department of Didactics of Languages, Arts and Sports. Faculty of Education. University of Málaga. Campus Teatinos, s/n. Málaga (29071), Spain. ${ }^{a}$ ORDIC: https://orcid.org/0000-0001-7843-9054, ${ }^{\mathrm{c} O R D I C:}$ https://orcid.org/0000-0001-9265-6071, ${ }^{\mathrm{d}}$ ORCID: https://orcid.org/0000-00034501-0088, ${ }^{\mathrm{b}}$ Cooperative of Evaluation and Research Services. 210 Calle José Oliver, San Juan, (00918). Puerto Rico. ORDIC: https://orcid.org/0000-00019638-3349, Email: $\quad$ juanlucas@uma.es, birleyton@gmail.com, cremades@uma.es, ${ }^{\mathrm{d}}$ sortega@uma.es
\end{abstract}

The objective of this study is to determine the opinions of university students undergoing primary school teacher training to develop language teaching material for patients from the Children's Hospital of Málaga, Spain, using the Service Learning (SL) methodology. Students evaluated this methodology by answering a 16-question questionnaire validated by external researchers. Academic performance was analysed using the Student's t-test by comparing grades between an intervention and a control group. The results indicated improvements in several areas, including: the level of engagement, transversal competencies, academic performance, level of student satisfaction, and acquisition of teaching material related to the subject.

Key words: Service Learning, Academic Performance, Higher Education, Teaching Material, Primary School Teacher Training.

\section{Introduction}

The proposal of the European Higher Education Area (Espacio Europeo de Educación Superior, hereby EEES) for European universities led to a significant reform in both curricula and methodology at the beginning of the 21 st century, not only to include new academic and cultural contexts but also to reconceptualise these institutions (Zabala 2006) and build more just and supportive societies that stimulate personal development (Puig et al., 2011). The objective of this proposal was to create European citizenship based on shared social values in order to reduce inequalities (Bologna Declaration 1999; London Communiqué 2007; 
Salamanca Demonstration 2001), as well as develop inter- and trans-disciplinary approaches to eradicate poverty, intolerance, and violence (UNESCO 1998). EEES initiatives involved educational reforms and innovation in competency based training, self-learning, tutoring and the use of new technologies. This approach led to an increase in the use of effective methodologies in university classrooms (Calvo-Bernardino \& Mingorance-Arnáiz 2009) to create a training model focused on practice through small Creative Research Groups (Andreu, Sanz \& Serrat 2009; De Miguel 2006).

The SL framework is based on dynamic methodologies, which encourage research and help promote values such as equality, solidarity and tolerance. The use of this methodology in basic and higher education has increased significantly since the 1990s (Luna 2010) and spread from the United States and Argentina to other countries. The participating students offer community services based on specific needs and curricular guidelines (Escofet et al., 2016). However, Learning Support (LS) is having its greatest impact in initial teacher training at the university level thanks to the studies of Furco (2001), Tedesco et al., (2008), Folgueiras \& Martínez (2009), Martínez (2010), Mangas \& Martínez-Odría, (2012), Rubio, Prats \& Gómez (2013), and García \& Sánchez (2017). LS is defined as an educational strategy used for developing sustainability and social responsibility competencies (Vázquez 2015), as it guarantees equality in the service provided and effective learning (Furco 1996). Therefore, both the customer and service provider benefit (Furco 1996; Furco \& Billig 2002). The objective of this approach is to encourage students to develop essential competencies established by UNESCO (2014), including critical analysis, systematic reflection, collaborative decision-making, and a sense of responsibility to present to future generations. In this respect, Eyler \& Giles (1999) found that higher education students who participated in LS-based projects obtained a greater understanding of real-life problems.

Universities as institutions should be strongly committed to social justice from an economic, labour and ethical point of view (Naval \& Ruiz-Corbella 2012), creating relationships with communities and providing comprehensive training according to social demands, especially at the local level. Higher education should train not only qualified professionals but also committed, attentive and critical citizens; LS educational proposals meets these criteria (Estrella Chamber, Díaz Pareja \& Ortega-Tudela 2017) because of their commitment to teaching and learning, as well as their focus on universities' social responsibility (Folgueiras 2014). Therefore, the concept of 'university extension' adopted in the initial proposal of the EEES has evolved into 'university social responsibility' over recent decades (Tapia 2008).

Different terms have been used to define LS, including: a 'methodological strategy' (Bednarz et al., 2008; Reinders 2010); 'methodology' (Ferran \& Guinot 2012; Furco 2003; Puig 2009; Rodríguez 2014; Tapia 2008); 'pedagogical proposal' (Cecchi 2006); and 'educational activity' (Puig et al. 2007). For these authors, LS allows students to acquire logical, relevant and useful information, and learn curricular content, values and emotions (Puig et al., 2007; 
Cho 2006; Robinson \& Meyer 2012). Furthermore, LS combines learning processes with community services through well-defined projects in which participants learn to address and solve real-life problems for the improvement of local communities or agents (Puig et al., 2006).

The concept of 'service' should not be confused with 'solidarity initiatives of a systematic nature with limited long-term effects and little correlation with curricular content' (Vázquez 2015 , p. 195). These activities are not meant to provide volunteering or vocational services (Tejada 2013), or campaigns that target solidarity services which are not focused on student learning (Uribe 2018). Instead, they facilitate participation of the community and society in teaching children and the youth (Escofet et al., 2016; Vázquez, Liesa \& Lozano 2017). A clear example is research projects that focus on social problems or the neighbourhoods inhabited by students who, without involving the community, offer guidelines or proposals for improvement; as such, 'the initial research project becomes a service to the community' (Amat, Moliner \& Rubio 2014, 10).

The main benefit of LS in primary and secondary education, particularly in the university setting, is the promotion of learning from experience, cooperative work and reflection on action (Puig et al., 2011). The results of the studies cited in this article have shown that the benefits of LS include critical thinking, higher civic and social responsibility, development of emotions and values, giving meaning to acquired theoretical knowledge, personal and professional development, and improvement in the social environment and institutions involved in the projects. LS is being increasingly used in educational institutions and encourages the 'learn to be' and 'learn to live together' approaches (Bisquerra 2008; Puig 2009), which are two of the four pillars of education detailed in the Delors Report (1996).

LS is adequately implemented through correct planning and organisation, so that teaching and learning processes are effective and directly relate to real-life problems. Naval et al., (2011), Cámara et al., (2017) and Mass (1998) reported that LS-based educational projects should: 1) consider students the protagonists and thus value their opinions; 2) address reallife problems; 3) be directly related to curricular objectives; 4) execute the project; and 5) stimulate student reflection on community services. LS should also address relevant social and ethical issues, and improve interpersonal relationships between students and the community. The proposed activities should be oriented towards cooperative and collaborative work, allowing the assessment of values and counter values (Martínez 2009). Within such an organisational structure, LS promotes the association between academic learning, social transformation, dialogue with communities, and student engagement in learning (Tejada 2013).

Several studies conducted in Spain evaluated the use of LS in primary school teacher training with objectives similar to those proposed in the present study. García Gómez (2011) 
evaluated more than 80 students from the University of Almería, who carried out action research, and acknowledged the need to improve pedagogical practices for the improvement of democracy and justice. Gómez, Bartoll \& Puig (2013) assessed 84 students from the Jaume I University and found that students and future teachers significantly improved social and citizen competencies. Peris, Gómez \& Puig (2014) evaluated students of early childhood teaching that provided physical education to children with functional diversity. In terms of early childhood and primary education, students from the Universities of Barcelona and Girona participated in an LS-based co-design project, in which González et al., (2016) highlighted how students connected theoretical academic training and practice through selfexperience, which resulted in a more contextualised perspective of university teaching. It is worth highlighting that Gómez, Bartoll \& Puig (2015) evaluated a sample of 346 students and found significant changes in their opinions about the sociocultural reality, especially in terms of understanding disabilities. As in the present study, Estrella, Pareja \& Ortega-Tudela (2017), from the University of Jaén, observed that students prepared information and communication technology material to address diversity and were able to develop creativity as well as social values and awareness. Furthermore, García García \& Gavira (2017) analysed a population of 191 students from the University of Cádiz who learned from common events in real-life. This study group understood the importance of their practice to society and created a climate of trust that stimulated free and critical thinking, allowing them to better understand each other, which was essential for addressing diversity.

\section{Objectives}

The primary objective of this study is to assess and describe the opinions of university students involved in LS projects and evaluate their academic performance. The specific research objectives were to: (1) determine the motivations of students, (2) determine the degree of development of transversal competencies, (3) evaluate student activities, (4) determine the level of adequacy of, and student satisfaction with, the project, (5) identify areas of improvement, and (6) analyse academic performance through grades.

\section{Materials and Methods}

\subsection{Study}

This quantitative study collected data using a questionnaire with closed questions and collected the scores obtained by students enrolled in a Spanish language teaching course. Data was analysed using descriptive and inferential statistics. The aforementioned procedures are detailed in the data collection, questionnaire results, and analysis of academic performance sections. This study has an exploratory, descriptive design as its objective was to analyse LS as an educational methodology during the teaching-learning process. As evidence in the literature is scarce, little is known about this topic, which encouraged the 
researchers to develop this study with the intention of promoting future lines of research. In this respect, the number of LS-based projects that involve developing teaching material is limited, and most of these studies focus on applying student activities as collaborative tasks.

\subsection{Study Sample}

Two groups of students who took the LS-based Spanish language teaching course answered the questionnaire $(n=115)$. The rate of response to the questionnaire was $85 \%(98 / 115)$. The number of female respondents was significantly higher than that of male respondents $(38 \%$ [n $=37$ ] versus $19 \%$ [ $\mathrm{n}=19]$, respectively) (Figure 1). There was higher enrolment in group D $(58 \%, \mathrm{n}=57)$ compared to group $\mathrm{F}(42 \%, \mathrm{n}=41)$.

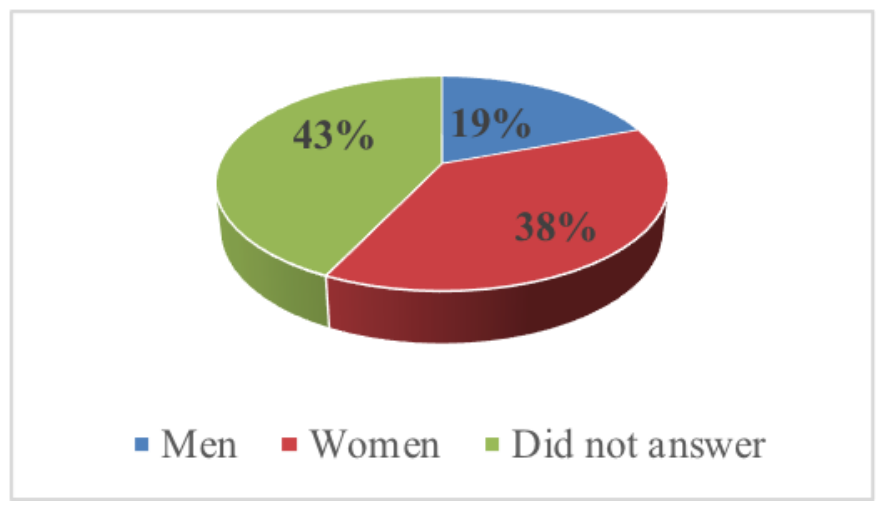

Figure 1: Questionnaire respondents by gender

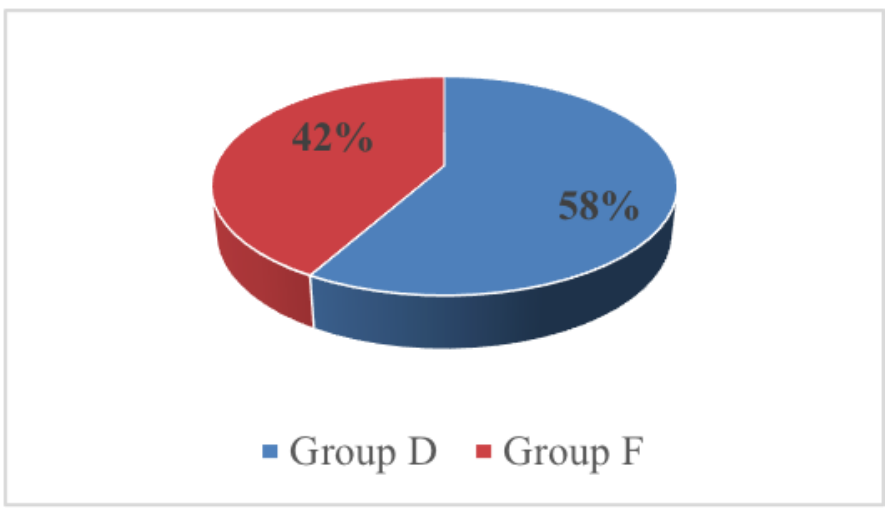

Figure 2: Questionnaire respondents by study group

\subsection{Project rationale}

This SL project was developed during the first semester of the 2018-2019 academic year, and included 115 students from groups D and F in their second year of the Primary Education degree at the University of Malaga (which targets primary school students). The project was integrated in a Spanish language teaching course and evaluated two specific competencies using the LS methodology. The first competency (Code 2.07) was related to 'collaborating 
with different sectors of the educational and social community and promoting democratic education for active citizenship'. The other competency (Code 2.09) was related to 'having individual and collective responsibility to achieve a sustainable future'.

This project was done in collaboration with the Alonso Quijano Foundation. This private non-profit organisation contributes to comprehensive personal development by promoting cultural and educational initiatives, especially those aimed at improving reading. Its projects include 'Improvement with books' a campaign intended to minimise the negative impact of the hospitalisation of children at the Maternal and Children's Hospital of Malaga and help them continue studying while in hospital. For this purpose, this organisation developed a book loan service 'Library on wheels' to allow hospitalised children to have access to reading and educational material, as well as technical assistance and support by qualified professionals and volunteers who encourage reading, answer questions and provide guidance.

The books available in the 'Library on wheels' came from private donations and included stories, comics and technical books on different topics (e.g., dinosaurs and other animals). Therefore, university students were encouraged to draft books or teach material that included recreational activities which fell under the five areas of the Primary Education Language Curriculum, as well as different types of texts prepared by them, including stories, poems, tongue twisters, riddles and illustrations (created by students or freely available on the internet). The curricular content of the course programme was put into practice by creating 21 educational and visually appealing books with different themes and teaching proposals in language, literature and communication.

\subsection{Data collection}

Data was collected using a questionnaire elaborated and validated by Escofet et al., (2016) to assess the opinions of university students involved in SL projects. The questionnaire contained 16 simple, scalar, inclusive and evaluative questions (dichotomous or multiple choice). The first six questions were designed to identify the participants, the other ten questions (five open and five closed) assessed acquired skills, and the remaining questions evaluated student participation in the project.

As this questionnaire was generic and could be adopted in any study with a similar objective, some questions were omitted to adapt to the requirements of this particular project. For this purpose, the following changes were made: of the first six questions in the 'service' section, only the last two were used because the information from the first four questions was the same for all participants (i.e., that the project belonged to the area of 'educational support' aimed at collaborating with an institution), and that the type of service was indirect (creation of teaching material). Moreover, two questions related to 'student participation' were omitted 
from the second group as the project evaluated a university course; therefore, asking who carried out the activity and what motivated them to do so was irrelevant to this research.

The questions were grouped for data analysis, and the following categories were created (Table 1).

Table 1: Categories and content of the questionnaire

\begin{tabular}{|c|c|c|}
\hline Category & Content & Questions \\
\hline Service & Assessment of activities & 4,5 , and 6 \\
\hline Competencies & $\begin{array}{l}\text { Degree of development of } \\
\text { transversal skills }\end{array}$ & 7 and 8 \\
\hline \multirow{6}{*}{ Participation } & Level of interest in the project & 9 \\
\hline & $\begin{array}{l}\text { Relation of the student with the } \\
\text { project }\end{array}$ & 11 \\
\hline & $\begin{array}{c}\text { Degree of student satisfaction } \\
\text { with the project }\end{array}$ & 13 \\
\hline & Suitability of the project & 14 \\
\hline & $\begin{array}{l}\text { Motivation to collaborate on } \\
\text { similar projects }\end{array}$ & 15 \\
\hline & Areas of improvement & 16 \\
\hline
\end{tabular}

The questionnaire was answered by two groups of students (D and F) after completing and presenting the project. The questionnaire was anonymous, and students were asked to deliver it within 2 weeks in a ballot box located in a department seminar room. Of the 115 participating students, 98 answered the questionnaire.

The academic performance of the two groups of students was evaluated. The first group was comprised of students that developed the project using SL methodology and answered the questionnaire. The second group included students who took the same course 2 years before the beginning of the study but did not develop LS-based projects. The university course was taught by the same teacher. Performance was assessed according to the following distribution: $40 \%$ for the exam score, $25 \%$ for the group project (whether based on LS or not), $10 \%$ for attitude and participation, and $25 \%$ for the execution of three individual activities, which subsequently became part of the SL project. 
International Journal of Innovation, Creativity and Change. www.ijicc.net

Volume 15, Issue 5, 2021

\section{Results}

The questionnaire was analysed according to the alternatives described in the data collection section, and descriptive statistics were used to evaluate the answers.

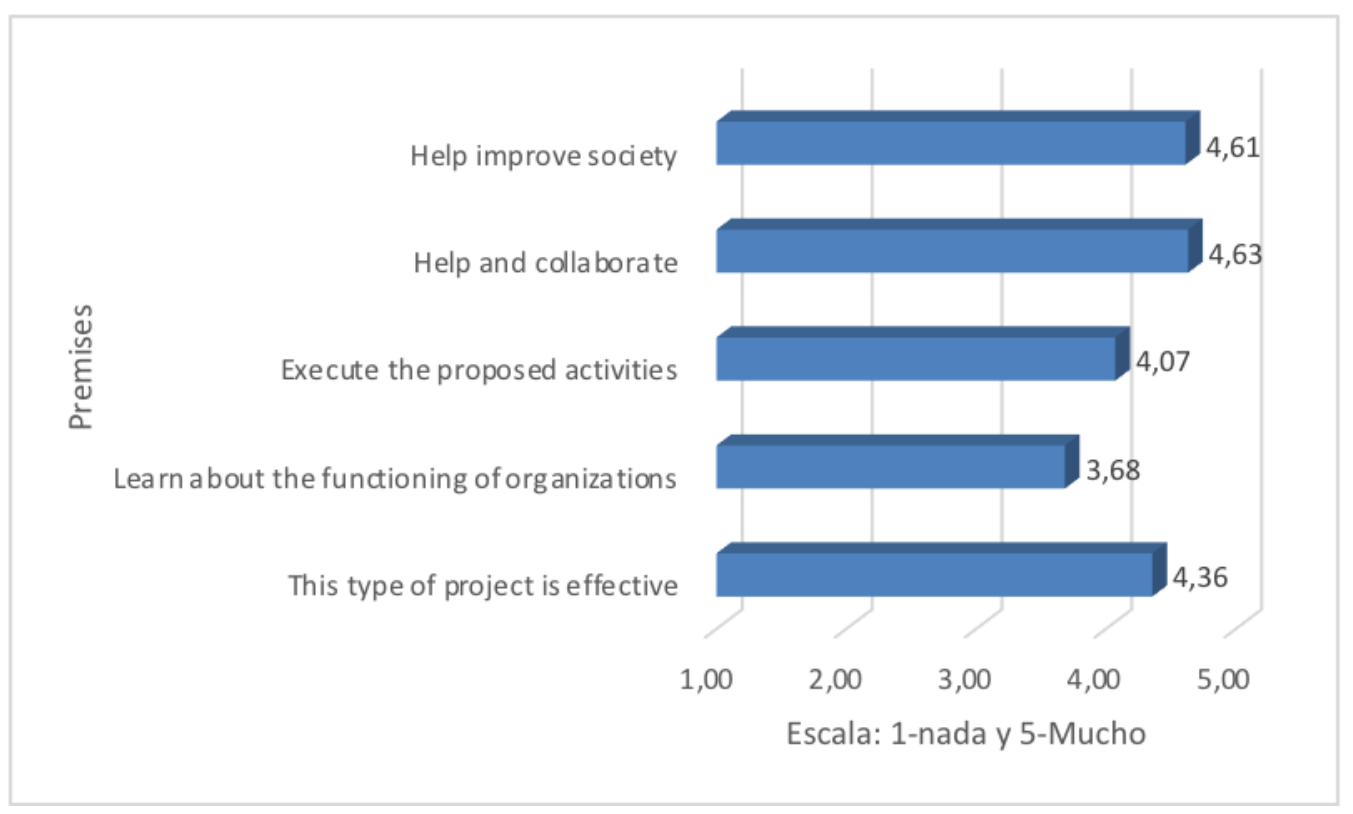

Figure 3: Level of student engagement in the project

The mean score of engagement in the project was high, highlighting the desire to 'help and collaborate' and 'positively contribute to society' (Figure 3 ).

With regard to the development of transversal skills, students believed that LS significantly contributed to the development of most of the skills described in the questionnaire. 
International Journal of Innovation, Creativity and Change. www.ijicc.net

Volume 15, Issue 5, 2021

Table 2: Transversal skills developed by students $(n=98)$. Scale: 1 , low; 5 , high. A score of zero indicated not having developed LS competencies

\begin{tabular}{|c|c|c|c|c|c|c|}
\hline & $\mathbf{0}$ & 1 & 2 & 3 & 4 & 5 \\
\hline $\begin{array}{l}\text { Know and understand ideas and } \\
\text { concepts }\end{array}$ & $0 \%$ & $6 \%$ & $2 \%$ & $20 \%$ & $46 \%$ & $24 \%$ \\
\hline Analyse and summarise data & $0 \%$ & $5 \%$ & $4 \%$ & $20 \%$ & $43 \%$ & $24 \%$ \\
\hline Organise and plan & $0 \%$ & $5 \%$ & $5 \%$ & $8 \%$ & $29 \%$ & $53 \%$ \\
\hline Make decisions & $0 \%$ & $7 \%$ & $1 \%$ & $3 \%$ & $33 \%$ & $53 \%$ \\
\hline Solve problems & $0 \%$ & $6 \%$ & $3 \%$ & $10 \%$ & $34 \%$ & $47 \%$ \\
\hline $\begin{array}{l}\text { Understand information and } \\
\text { communication technology }\end{array}$ & $1 \%$ & $7 \%$ & $11 \%$ & $11 \%$ & $31 \%$ & $37 \%$ \\
\hline Search and manage information & $0 \%$ & $6 \%$ & $2 \%$ & $11 \%$ & $45 \%$ & $35 \%$ \\
\hline Communicate orally and in writing & $0 \%$ & $7 \%$ & $1 \%$ & $7 \%$ & $28 \%$ & $57 \%$ \\
\hline Speak foreign languages & $13 \%$ & $11 \%$ & $17 \%$ & $18 \%$ & $12 \%$ & $8 \%$ \\
\hline Express feelings & $0 \%$ & $5 \%$ & $6 \%$ & $12 \%$ & $37 \%$ & $\mathbf{3 8 \%}$ \\
\hline Develop teamwork & $1 \%$ & $6 \%$ & $4 \%$ & $5 \%$ & $18 \%$ & $64 \%$ \\
\hline Reason critically & $0 \%$ & $6 \%$ & $2 \%$ & $11 \%$ & $40 \%$ & $41 \%$ \\
\hline Have ethics & $0 \%$ & $6 \%$ & $1 \%$ & $10 \%$ & $32 \%$ & $\mathbf{5 0 \%}$ \\
\hline Recognise diversity and multiculturality & $1 \%$ & $6 \%$ & $5 \%$ & $12 \%$ & $29 \%$ & $47 \%$ \\
\hline Negotiate & $6 \%$ & $6 \%$ & $7 \%$ & $31 \%$ & $22 \%$ & $22 \%$ \\
\hline Adapt to new situations & $1 \%$ & $8 \%$ & $1 \%$ & $14 \%$ & $35 \%$ & $40 \%$ \\
\hline Be creative and innovative & $0 \%$ & $5 \%$ & $2 \%$ & $5 \%$ & $20 \%$ & $65 \%$ \\
\hline Work independently & $0 \%$ & $7 \%$ & $4 \%$ & $14 \%$ & $35 \%$ & $39 \%$ \\
\hline Be a leader & $1 \%$ & $6 \%$ & $13 \%$ & $21 \%$ & $29 \%$ & $26 \%$ \\
\hline Have initiative and be entrepreneurial & $0 \%$ & $5 \%$ & $4 \%$ & $10 \%$ & $35 \%$ & $46 \%$ \\
\hline Promote quality improvement & $0 \%$ & $5 \%$ & $2 \%$ & $8 \%$ & $31 \%$ & $54 \%$ \\
\hline $\begin{array}{l}\text { Assess the social and environmental } \\
\text { impact of the proposed actions }\end{array}$ & $0 \%$ & $5 \%$ & $3 \%$ & $13 \%$ & $35 \%$ & $43 \%$ \\
\hline Design and manage projects & $0 \%$ & $5 \%$ & $3 \%$ & $13 \%$ & $35 \%$ & $43 \%$ \\
\hline $\begin{array}{l}\text { Evaluate the sustainability of proposals } \\
\text { and actions }\end{array}$ & $0 \%$ & $6 \%$ & $2 \%$ & $11 \%$ & $33 \%$ & $47 \%$ \\
\hline
\end{tabular}


Most of the answers (67-86\%) obtained scores of 4 or 5 on a scale of 1 to 5 , in which a score of zero indicated not having developed LS competencies. The transversal skills with the lowest scores were 'speaking foreign languages', 'negotiating' and 'leading' (Table 2).

The majority of responses on the utility of LS-based activities obtained scores 4 or 5 (Table 3). 'Knowing the subject matter' and 'developing curricular content' presented the highest scores, whereas 'participating in university, local, and municipal activities' and 'reflecting on university content' had the lowest scores.

Table 3: Student assessment of LS-based activities $(n=98)$

\begin{tabular}{llllll}
\hline \hline & $\mathbf{1}$ & $\mathbf{2}$ & $\mathbf{3}$ & $\mathbf{4}$ & $\mathbf{5}$ \\
\hline \hline Develop curricular content & $0 \%$ & $3 \%$ & $17 \%$ & $\mathbf{4 6 \%}$ & $\mathbf{3 4 \%}$ \\
Address real-life problems & $0 \%$ & $7 \%$ & $23 \%$ & $\mathbf{2 7 \%}$ & $\mathbf{4 3 \%}$ \\
Understand social needs & $0 \%$ & $8 \%$ & $24 \%$ & $\mathbf{3 1 \%}$ & $\mathbf{3 7 \%}$ \\
Collaborate in an organisation or association & $1 \%$ & $7 \%$ & $24 \%$ & $\mathbf{1 9 \%}$ & $\mathbf{4 7 \%}$ \\
Engage in social activities & $0 \%$ & $3 \%$ & $24 \%$ & $\mathbf{3 0 \%}$ & $\mathbf{4 3 \%}$ \\
Participate in university, local and municipal activities & $3 \%$ & $12 \%$ & $30 \%$ & $28 \%$ & $28 \%$ \\
Engage in research & $0 \%$ & $7 \%$ & $22 \%$ & $\mathbf{4 0 \%}$ & $\mathbf{3 0 \%}$ \\
Learn curricular content & $0 \%$ & $6 \%$ & $21 \%$ & $\mathbf{4 2 \%}$ & $\mathbf{3 1 \%}$ \\
Reflect on university content & $0 \%$ & $5 \%$ & $33 \%$ & $\mathbf{3 3 \%}$ & $\mathbf{3 0 \%}$ \\
Comply with the proposed actions & $0 \%$ & $9 \%$ & $21 \%$ & $\mathbf{2 8 \%}$ & $\mathbf{4 2 \%}$ \\
Implement professional development & $0 \%$ & $6 \%$ & $29 \%$ & $\mathbf{3 0 \%}$ & $\mathbf{3 6 \%}$ \\
Help improve society & $1 \%$ & $4 \%$ & $19 \%$ & $\mathbf{2 1 \%}$ & $\mathbf{5 4 \%}$ \\
Connect theory with practice & $1 \%$ & $3 \%$ & $22 \%$ & $\mathbf{2 6 \%}$ & $\mathbf{4 7 \%}$ \\
Understand the professional scope of the project & $0 \%$ & $4 \%$ & $24 \%$ & $\mathbf{3 7 \%}$ & $\mathbf{3 5 \%}$ \\
Reflect on university content & $1 \%$ & $6 \%$ & $35 \%$ & $31 \%$ & $27 \%$ \\
Cultivate values & $0 \%$ & $4 \%$ & $16 \%$ & $\mathbf{2 7 \%}$ & $\mathbf{5 2 \%}$ \\
Know the subject matter & $0 \%$ & $0 \%$ & $14 \%$ & $\mathbf{4 9 \%}$ & $\mathbf{3 4 \%}$ \\
\hline \hline
\end{tabular}

Another factor that was analysed was the adequacy of the project based on four basic premises (Figure 4). 
International Journal of Innovation, Creativity and Change. www.ijicc.net

Volume 15, Issue 5, 2021

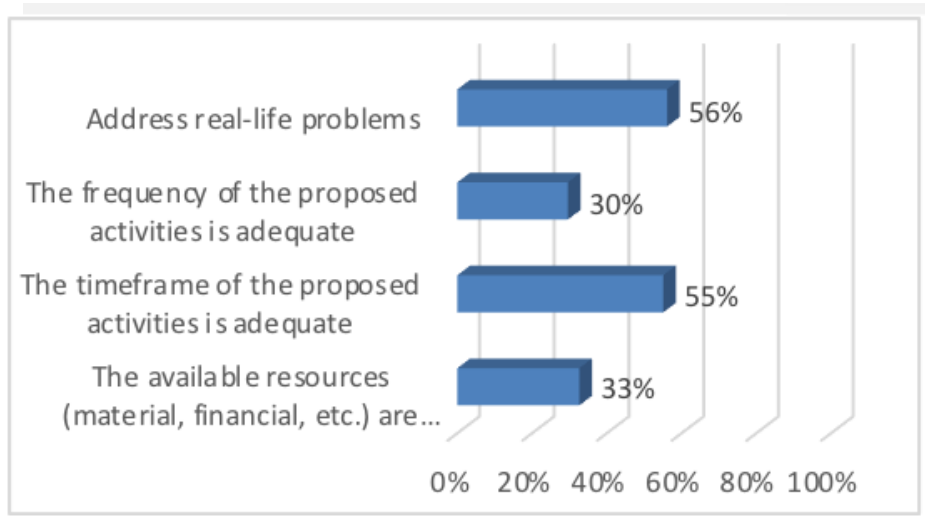

Figure 4: Adequacy of the project based on four basic premises

The topics with the highest scores were 'addressing real-life problems' and 'the timeframe of the activities is adequate'.

With respect to the degree of satisfaction, most of the answers obtained scores of 4 or 5 (Figure 5), indicating that students were generally satisfied with the LS methodology, especially in terms of the project's impact and the service it provided.

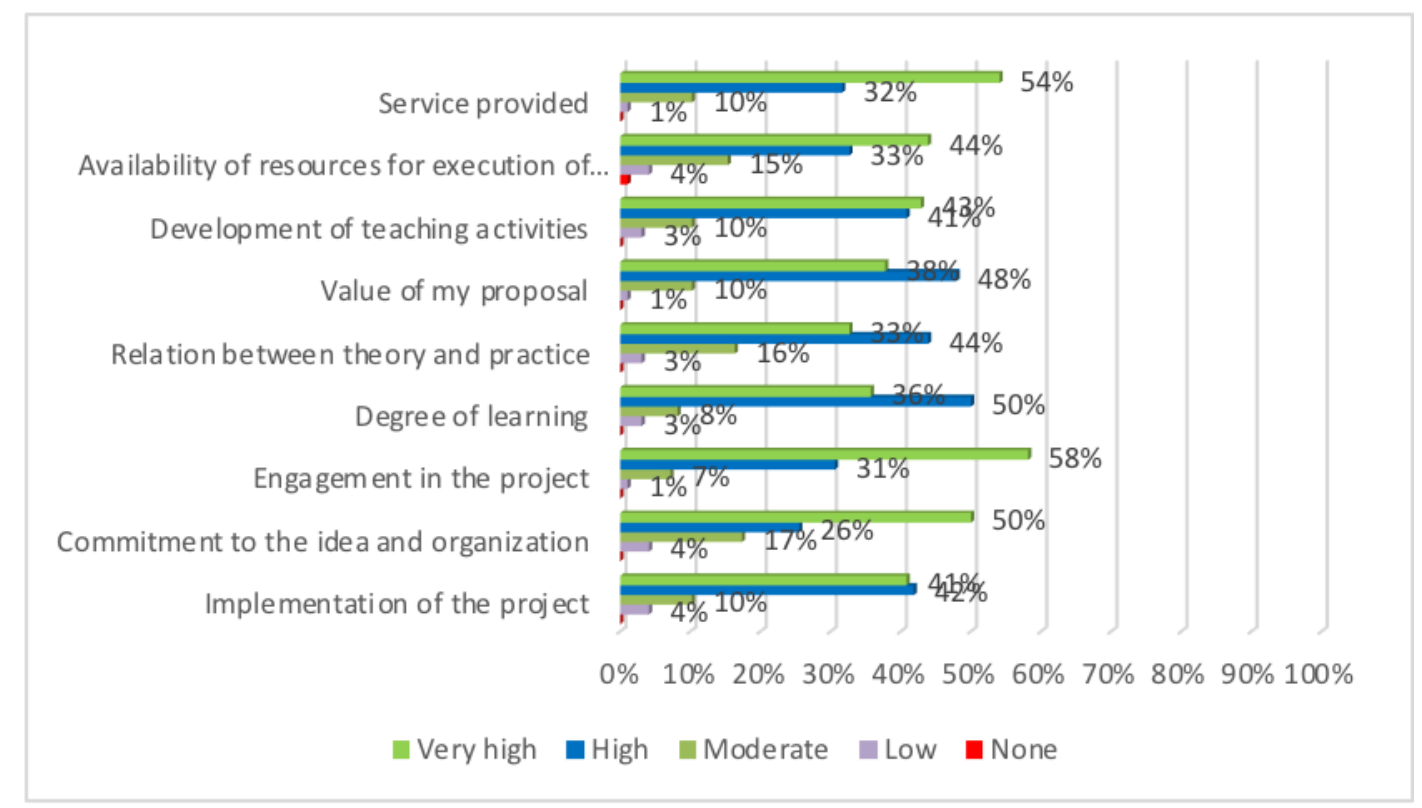

Figure 5: Degree of student satisfaction with the project

The areas of improvement were organisational factors (schedules, meetings, resources and the duration of activities) and the 'impact of the project'. These results demonstrate that LS projects should be adopted by other institutions, become disseminated through different media, and create space for the exchange of experiences. 
International Journal of Innovation, Creativity and Change. www.ijicc.net

Volume 15, Issue 5, 2021

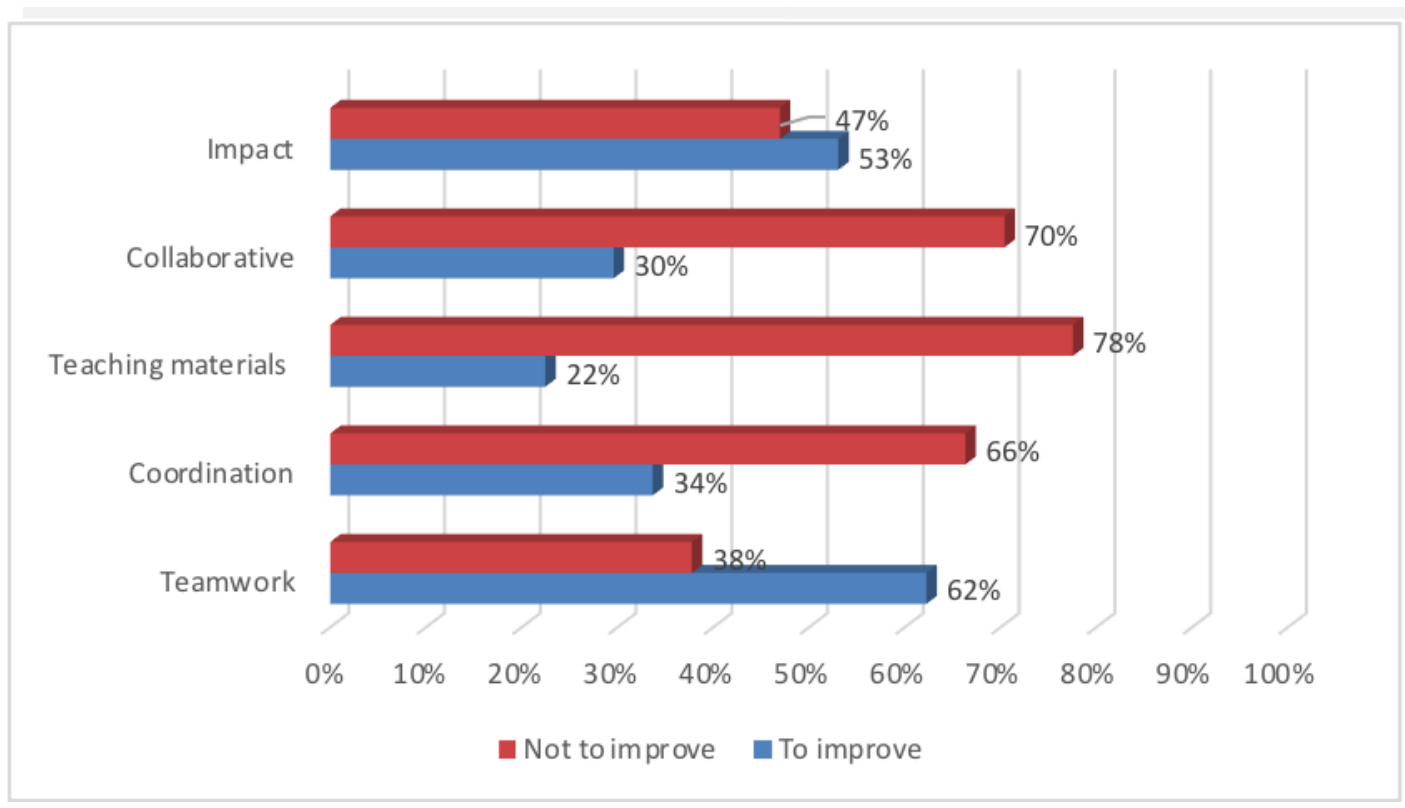

Figure 6: Areas of improvement

\subsection{Analysis of academic performance}

Another data source was the analysis of academic performance in the Spanish language teaching course based on the grades that were obtained. For this analysis, the sample was divided into two groups, those who took the course using LS (intervention group, IG), and those who took the same university course but developed projects not based on LS (control group, CG). Student's t-test was used in independent samples which considered the group to be a categorical variable, and performance on a scale of 1 to 10 to be a quantitative variable. The objective of using this approach was to test the hypothesis that the average grades of the groups were equal.

The assumptions of independence, normality and homoscedasticity were verified before performing the Student's t-test. Based on the Central Limit Theorem and sample size $(\mathrm{N}=$ 115 and 77 in the IG and CG, respectively), the violation of the normality assumption (asymmetry and outliers) did not affect the statistical results (Brown, Ruiz \& San Martín 2009). Therefore, we assumed that academic performance presented a normal distribution. Another important consideration was the use of a one-way analysis because the performance of the IG was expected to be higher than that of the CG. P-values smaller than 0.05 were considered statistically significant. 
International Journal of Innovation, Creativity and Change. www.ijicc.net

Volume 15, Issue 5, 2021

Table 4: Student's t-test results for independent samples

\begin{tabular}{|c|c|c|c|c|c|c|c|c|c|c|}
\hline & & \multicolumn{2}{|c|}{$\begin{array}{l}\text { Levene's test } \\
\text { for equality of } \\
\text { variances }\end{array}$} & \multicolumn{7}{|c|}{ T-test for equality of means } \\
\hline & & \multirow{2}{*}{$F$} & \multirow{2}{*}{$\begin{array}{c}\text { Signi } \\
\text { fican } \\
\text { ce }\end{array}$} & \multirow{2}{*}{$\mathrm{t}$} & \multirow{2}{*}{$\begin{array}{l}\text { Degree } \\
\mathrm{s} \text { of } \\
\text { freedo } \\
\mathrm{m}\end{array}$} & \multirow{2}{*}{$\begin{array}{l}\text { Level of } \\
\text { significan } \\
\text { ce (two- } \\
\text { way } \\
\text { analysis) }\end{array}$} & \multirow{2}{*}{$\begin{array}{c}\text { Mean } \\
\text { difference }\end{array}$} & \multirow{2}{*}{$\begin{array}{l}\text { Error of } \\
\text { the mean }\end{array}$} & \multicolumn{2}{|c|}{$\begin{array}{c}95 \% \text { confidence } \\
\text { interval }\end{array}$} \\
\hline & & & & & & & & & Low & High \\
\hline \multirow{2}{*}{$\begin{array}{l}\text { Academic } \\
\text { performance }\end{array}$} & $\begin{array}{l}\text { Equal } \\
\text { variances }\end{array}$ & 14.19 & 0.00 & $\begin{array}{c}5.1 \\
7\end{array}$ & 190 & 0.00 & 0.73 & 0.14 & 0.45 & 1.00 \\
\hline & $\begin{array}{l}\text { Unequal } \\
\text { variances }\end{array}$ & & & $\begin{array}{c}4.5 \\
3\end{array}$ & 96.86 & 0.00 & 0.73 & 0.16 & 0.41 & 1.04 \\
\hline
\end{tabular}

The results of the Student's t-test are shown in Table 4. The results of Levene's F-test (14.19) and its level of significance $(\alpha=0.00)$ allowed us to reject the hypothesis on the equality of variances. Therefore, the results of the Student's t-test were used assuming that variances were equal. In addition, the value of the statistic $t=5.17$ and $p<0.05$ allowed us to reject the null hypothesis of the equality of means. The average performance of the IG was significantly higher than that of the CG.

\section{Conclusion}

The results showed that most students approved of the proposed project and used LS to develop language teaching material for patients of the Maternal and Children's Hospital of Malaga, in collaboration with the Alonso Quijano Foundation.

Furthermore, with respect to the level of engagement in the project, it is worth highlighting students' desire to help, collaborate and positively contribute to society; these results are in accordance with the findings of Ayuste González et al., (2016) who argued that 'the motivational effect of these experiences is critical for promoting the acquisition of knowledge and the necessary skills to exercise teaching' (p. 179).

With regard to the development of transversal skills, students considered LS to significantly contribute to most of the competencies described in the questionnaire, especially the 'development of oral and written communication', 'teamwork', and 'being creative and innovative'. In contrast, the scores for transversal skills such as 'negotiating' and 'leading' were low. Uribe Sepúlveda (2018) evaluated university teaching students and reported that personal and professional development, as well as ethics, valuation of diversity, teamwork, moral values, and attitudes were improved. LS allows university students to acquire skills in different areas and develop the social and civic awareness necessary for future teachers (Cámara Estrella et al., 2017; Gil et al., 2013, 2015). 
The areas 'knowing the subject matter' and 'developing curricular content' had the highest scores, whereas 'engaging in university, local and municipal activities' and 'reflecting on university content' had the lowest scores. Students reported that the project addressed reallife problems, demonstrating that this sample of people was aware of the importance of, and need for, this project. This finding is similar to that of García García (2017) in which students valued the opportunity to be active agents of learning in a social context (in other words, the fact that 'they were heard, made decisions and put them into action', and were able to develop practical knowledge by cooperating with other people, in this case, hospitalised children).

Additionally, the degree of student satisfaction was high (scores 4 and 5), highlighting the general 'commitment to the project, proposal and NGO', 'service provided', and 'degree of learning'.

The most relevant area of improvement was related to organisational aspects. With regard to pedagogical factors, students perceived a strong relationship between theoretical and practical training, and between academic and experiential learning. LS favours a more contextualised and holistic perspective of higher education, as shown in the study of Ayuste González (2016). The potential for improving the organisational structure of this project may be closely related to the experience and training of teachers, who acknowledge that this challenge goes beyond the preparation of a specific course.

The academic performance scores were significantly higher in the IG than in the CG. This result might be related to students' opinion that only minor changes should be made in curricular aspects of the project, and that the most valued activities are knowing the subject matter and developing curricular content. This conclusion is consistent with that of other studies that investigated the academic performance of students using LS projects (Cámara Estrella et al., 2017; Capella Peris 2014; García García \& Benítez Gavira 2017).

\section{Funding}

This research no specific grant from any funding agency in the public, commercial or not-forprofit sector.

\section{Declaration of interest statement}

The authors declare that they have no known competing financial interests or personal relationships that could have appeared to influence the work reported in this paper. 
International Journal of Innovation, Creativity and Change. www.ijicc.net

Volume 15, Issue 5, 2021

\section{REFERENCES}

Amat, A. F., Miravet, L. \& Serrano, L. R. (2014). Construyendo ciudadanía, crítica y activa: Experiencias sobre aprendizaje servicio en las universidades del estado español. Barcelona: Icaria Editorial.

Barrachina, L. A., Sanz-Torrent, M. \& Sellabona, E. S. (2009). Una propuesta de renovación metodológica en el marco del Espacio Europeo de Enseñanza Superior: Los pequeños grupos de investigación cooperativos. Revista interuniversitaria de formación del profesorado, 12(3), 111-126.

Bednarz, S. W., et al. (2008). Community Engagement for Student Learning in Geography. Journal of Geography in Higher Education, 32(1), 87-100.

Bernerdino, A. C. \& Mingorance, C. (2009). La estrategia de las universidades frente al Espacio Europeo de Educación Superior. Revista Complutense de Educación, 20(2), 319-342.

Bisquerra, R. (2008). Educación para la ciudadanía y convivencia: El enfoque de la educación emocional. Madrid: WoltersKluver.

Bologna Declaration. (1999). Declaración conjunta de los ministros europeos de educación. Bolonia. Disponible en: http://www.eees.es/pdf/Bolonia_ES.pdf

Cecchi, N. (2006). Aprendizaje-servicio en Educación Superior. La experiencia latinoamericana. En Presentación Seminario Internacional de Responsabilidad Social Universitaria. Aprendizaje Servicio Caracas. Disponible en http://www.zerbikas.es/categoria-producto/experiencias/

Cho, M. (2006). Artistically Serving: A Study of the Lake County's Arts-Based Service Learning Program. (Tesis doctoral) Universidad de Florida, Florida. Disponible en: http://etd.lib.fsu.edu/theses/available/etd-07102006-180525/.

Delors, J. (1996). Los cuatro Pilares de la educación. En La Educación Encierra un tesoro. Informe a la UNESCO de la Comisión internacional sobre la educación para el Siglo XXI, 91-103. Madrid: Santillana/UNESCO.

Díaz, M. M. (2006). Metodologías para optimizar el aprendizaje: Segundo objetivo del Espacio Europeo de Educación Superior. Revista interuniversitaria de formación del profesorado, 57, 71-92.

Escofet, A., Fogueiras, P., Luna, E., \& Palou, B. (2016). Elaboración y validación de un cuestionario para la valoración de proyectos de aprendizaje-servicio. Revista Mexicana de Investigación Educativa, 21(70), 929-949.

Estrella, A. C., Pareja, E. \& Tudela. J. M. (2017). Aprendizaje-servicio en la universidad: Ayudando a la escuela a atender a la diversidad a través de las TIC. Bordón. Revista de pedagogía, 69(3), 73-87. doi:10.13042/Bordon.2017.51320.

Eyler, J. \& Giles, D. E. (1999). Where's the Learning in Service Learning. San Francisco, CA: Jossey-Bass Publishers. 
International Journal of Innovation, Creativity and Change. www.ijicc.net Volume 15, Issue 5, 2021

Folgueiras, P. \& Martínez, M. (2009). El desarrollo de competencias en la universidad a través del Aprendizaje y Servicio Solidario. Revista Interamericana de Educación para la Democracia, 2(1), 55-76.

Folgueiras, P. (2014). Aprendizaje y servicio, investigación y universidad. En A. F. Amat, L. M. Miravet, \& L. R. Serrano (Eds.), Construyendo ciudadanía crítica y activa: experiencias sobre el aprendizaje servicio en las universidades del Estado español (pp. 147-166). Barcelona: Icaria.

Furco, A. \& Billig, S. (Eds.). (2002). Service Learning: The Essence of the Pedagogy. Greenwich, CT: Information Age Publication.

Furco, A. (1996). Service-Learning: A Balanced Approach to Experiential Education. En Expanding Boundaries: Serving and Learning. En Corporation for National Service (pp. 1-6). Columbia, MD: Cooperative Education Association.

Furco, A. (2001). Advancing Service-Learning at Research Universities. New Directions for Higher Education, 114, 67-78.

Furco, A. (2003). Issues of Definition and Program Diversity in the Study of Service Learning. En S. H. Billig y A. S. Waterman (Eds.), Studying Service-Learning: Innovations in Education Research Methodology (pp. 13-34). Mahwah: Lawrence Erlbaum Associates.

García, M. G. \& Gavira, R. B. (2017). Comprometiéndonos con “nuestra escuela": Un proyecto de Aprendizaje-Servicio para una formación del profesorado inclusiva. Revista de Educación Inclusiva, 7(2), 69-83.

García, M. G. y Calleja, L. S. (2017). El aprendizaje servicio y el desarrollo de las competencias emocionales en la formación inicial del profesorado. Contextos Educativos, 20, 127-145. doi:10.18172/con.2991.

Gómez, J. G., Bartoll, O. C., \& Puig, M. M. (2013). La adquisición de la competencia social y ciudadana en la universidad mediante el Aprendizaje-Servicio: Un estudio cuantitativo y cualitativo en el ámbito de la Educación Física. Revista Internacional de Educación para la Justicia Social, 2(2), 89-108.

Gómez, J. G., Bartoll, O. C., \& Puig, M. M. (2015). The Impact of Service Learning on the Training of Pre-Service Teachers: Analysis from a Physical Education Subject. European Physical Education Review, 21(4), 467-484. doi:10.1177/1356336X15582358.

Gómez, T. G. (2011). Aportaciones ciudadanas desde el aprendizaje servicio: universidad, escuela y comunidad conectadas. Revista Interuniversitaria de Formación del Profesorado, 25(2), 125-141.

González, A. A., Roig, A. E., Suari, N. O. \& Juanola, M. M. (2016). Aprendizaje-servicio y codiseño en la formación de maestros: Vías de integración de las experiencias y perspectivas de los estudiantes. Bordón. Revista de pedagogía, 68(2), 169-183. doi:10.13042/Bordon.2016.68211. 
International Journal of Innovation, Creativity and Change. www.ijicc.net

Volume 15, Issue 5, 2021

London Communiqué. (2007). Ministros Europeos de Educación Superior. Hacia el Espacio Europeo de Educación Superior: respondiendo a los retos de un mundo globalizado. Disponible en: https://cutt.ly/Ztwb9z6

Luna, E. (2010). Del centro educativo a la comunidad: Un programa de aprendizaje-servicio para el desarrollo de ciudadanía activa. (Tesis doctoral). Universidad de Barcelona, Barcelona. Disponible en: http://diposit.ub.edu/dspace/bitstream/2445/42480/2/ELG_TESIS.pdf

Mangas, S. L. \& Martínez-Odría, A. (2012). La implantación y difusión del AprendizajeServicio en el contexto educativo español. Retos de futuro de una metodología de enseñanza-aprendizaje para promover la innovación en la Educación Superior. Revista del Congrés Internacional de Docència Universitària i Innovació 1(1), 1-14.

Martínez, M. (2009). Aprendizaje y servicio: Bases conceptuales y sentido normativo. En M. Raposo et al., El prácticum más allá del empleo. Formación vs Training (pp. 23-34). Santiago de Compostela: Imprenta Universitaria.

Martínez, M. (2010). Aprendizaje-servicio y construcción de ciudadanía activa en la Universidad: La dimensión social y cívica de los aprendizajes académicos. En M. Martínez, Aprendizaje servicio y responsabilidad social de las universidades (pp. 1126). Barcelona: Octaedro.

Merino, A. P., Díaz, M. \& Castellanos, R. (2009). Análisis de datos en ciencias sociales y de la salud I. Madrid: Editorial Síntesis.

Naval, C. \& Ruiz-Corbella, M. (2012). Aproximación a la responsabilidad social universitaria: La respuesta de la universidad a la sociedad. Bordón. Revista de Pedagogía, 64(3), 103-115. Recuperado de: http://recyt.fecyt.es/index.php/BORDON/article/view/22053/11359.

Naval, C., García, R., Puig, J. \& Santos, M. A. (2011). La formación ético-cívica y el compromiso social de los estudiantes universitarios. Encounters on Education, 12, 77 91.

Peris, C., Gil-Gómez, J., \& Martí-Puig, M. (2014). Service-Learning Methodology in Physical Education. Apunts. Educación Física y Deportes, 116, 33-43. doi:10.5672/apunts.2014-0983.es.(2014/2).116.03.

Puig J. M., Battle R., Bosh C., y Palos J. (2007). Aprendizaje servicio. Educar para la ciudadanía. Barcelona: Ministerio de Educación y Ciencia/Octaedro

Puig, J. M. (Coord.). (2009). Aprendizaje servicio (ApS). Educación y compromiso cívico. Barcelona: Graó.

Puig, J. M., Gijón, M., Martín, X., \& Rubio, L. (2011). Aprendizaje-servicio y Educación para la Ciudadanía. Revista de Educación, número extraordinario, 45-67 doi: 10.4438/1988-592X-0034-8082-RE

Reinders, H. (2010). The Promotion of Learning Processes through Service Learning in Higher Education. Zeitschrift Fur Padagogik, 56(4), 531-547.

Robinson, D. B., \& Meyer, M. (2012). Health Education and Interactive Drama: Findings from a Service Learning Project. Health Education Journal, 71(2), 219-228. 
International Journal of Innovation, Creativity and Change. www.ijicc.net Volume 15, Issue 5, 2021

Rodríguez, M. R. (2014). El aprendizaje-servicio como estrategia metodológica en la universidad. Revista Complutense de Educación, 25(1), 95-113.

Rubio, L., Prats, E. \& Gómez, L. (coord.). (2013). Universidad y sociedad. Experiencias de Aprendizaje servicio en la universidad. Barcelona: Universitat de Barcelona.

Salamanca (2001). Mensaje de la I Convención de Instituciones Europeas de Enseñanza Superior: perfilando un Espacio Europeo de Enseñanza Superior. Disponible en http://www.eees.es/pdf/Salamanca2001.pdf

Sepúlveda, P. (2018). Percepción de los estudiantes de educación inicial frente al desarrollo de experiencias formativas en modalidad $\mathrm{A}+\mathrm{S}$. Revista Electrónica de Investigación Educativa, 20(4), 110-122. doi:10.24320/redie.2018.20.4.1826.

Tapia, M.N. (2008). Aprendizaje y servicio solidario. Buenos Aires: Ciudad Nueva.

Tedesco, J. C., Hernaiz, I., Tapia, M. N. \& Rial, S. (2008). El aprendizaje-servicio en la educación superior: Una mirada analítica desde los protagonistas. Buenos Aires: Editorial Universitaria de Buenos Aires.

Tejada, J. (2013) La formación de las competencias profesionales a través del aprendizaje y servicio. Cultura y educación, 25(3), 285-294.

Toledo, S., Orús, M. L. \& Roy, A. L. (2017). Recreos Cooperativos e Inclusivos a través de la metodología de Aprendizaje-Servicio. Revista Electrónica Interuniversitaria de Formación del Profesorado, 20(1), 173-185. doi:10.6018/reifop.20.1.213181

UNESCO. (1998). Declaración final de la Conferencia Mundial de Educación Superior. Primera Conferencia Mundial de Educación Superior. París.

UNESCO. (2014). Roadmap for Implementing the Global Programme on Education for Sustainable Development. París. Disponible en http://unesdoc.unesco.org/images/0023/002305/230514e.pdf.

Verdera, V. (2015). El aprendizaje-servicio: una estrategia para la formación de competencias en sostenibilidad. Foro de Educación, 13(19), 193-212. doi:10.14516/fde.2015.013.019.009

Weigert, K. M. (1998). Academic Service Learning: Its Meaning and Relevance. New Directions for Teaching and Learning, 73, 1-8. doi: 10.1002/t1.7301

Zubillaga, A. \& Viciano, C. G. (2012). Aprendizaje-Servicio: propuesta metodológica para trabajar competencias. Portularia, XII-extra, 187-195 doi: 10.5218/prts.2012.0020 